\title{
Organophosphate Pesticides in Coastal Lagoon of the Gulf of Mexico
}

\author{
Guadalupe Ponce-Vélez ${ }^{1 *}$, Guadalupe de la Lanza-Espino ${ }^{2}$ \\ ${ }^{1}$ Laboratorio de Contaminación Marina, Instituto de Ciencias del Mar y Limnología, Universidad Nacional \\ Autónoma de México, Mexico City, México \\ ${ }^{2}$ Laboratorio de Hidrobiología, Instituto de Biología, Universidad Nacional Autónoma de México, Mexico City, México \\ Email: *ponce@cmarl.unam.mx
}

How to cite this paper: Ponce-Vélez, G. and de la Lanza-Espino, G. (2019) Organophosphate Pesticides in Coastal Lagoon of the Gulf of Mexico. Journal of Environmental Protection, 10, 103-117. https://doi.org/10.4236/jep.2019.102007

Received: October 31, 2018

Accepted: January 21, 2019

Published: January 24, 2019

Copyright $\odot 2019$ by author(s) and Scientific Research Publishing Inc. This work is licensed under the Creative Commons Attribution International License (CC BY 4.0).

http://creativecommons.org/licenses/by/4.0/

\begin{abstract}
The worldwide use of semi-persistent organophosphate pesticides has become increasingly frequent and notorious. Their presence is registered in both continental and coastal waters; the latter ones are known for their subtly balanced environmental richness, difficult to recover once lost. These xenobiotics compounds reach the coastal zone through rivers that have crossed human settlements, as well as through peripheral runoff water used to exterminate agricultural pests. In Mexico, a developing country, the use of pesticides for several decades has not been adequately regulated, which is why various coastal ecosystems are the accumulation areas of these agrochemicals used in the continent. In the Gulf of Mexico, one of the coastal systems of high fishing importance for many years is the lagoon of Alvarado and receives the discharges of two great rivers, Blanco, Limón and Papaloapan, which travel more than $200 \mathrm{~km}$ from its source to the sea, crossing large extensions of farmland where there are also livestock activities and the use of these pesticides. For this reason, the objective of this work was to determine the presence of organophosphate pesticides in the Alvarado lagoon at the Gulf of Mexico as a potential aspect of high impact contamination. Five pesticides have been identified in the lagoon sediments, of which the most important and highest concentrations are Dimethoate and Chlorpyrifos, with 75.65 $79.0 \mathrm{ng} / \mathrm{g}$ and $0.17-0.23 \mathrm{ng} / \mathrm{g}$ respectively, both internationally classified as moderately toxic. These concentrations were comparable to levels in other world regions with intense agricultural activity and vector control like the Mediterranean Sea and the lagoon of Alvarado was evidenced as a hot spot for the accumulation of these organophosphates with the high risk for the benthic organisms and for the human health when consuming these fishery products.
\end{abstract}




\section{Keywords}

Organophosphate Pesticides, Sediments, Coastal Lagoon

\section{Introduction}

Organophosphate pesticides (OPs) are the chemical compounds most used in the world, representing between $30 \%$ and $40 \%$ of insecticide sales in the planet [1] [2]. These compounds less persistent than organochlorine pesticides have a higher acute toxicity, with their biocide action affecting a larger diversity of organisms, and have a low cost, all of which favors their use to control various species that affect food-relevant crops as well as some vectors that represent risks to human health. In the Mexican agriculture areas have been used since the 1950s. Their main compounds are Chlorpyrifos, Dimethoate, Parathion and Malathion, which can degrade and produce "oxo analogues", often more toxic or persistent than the original molecules [3] [4]. The coastal zone is the final reservoir of much anthropic waste and the presence of this type of xenobiotics in tropical coastal ecosystems, particularly in coastal lagoons and estuaries, causes environmental stress and death in the biological communities that inhabit these natural areas and reflect the impact of urban, industrial and agricultural human activities [5]. The lagoon systems of the Gulf of Mexico are a clear example of highly productive ecosystems polluted by human residual contributions that cause biological damage [6] [7] [8] [9], often irreversible given the presence of complex mixtures of waste, such as organophosphate pesticides. In recent years, very complete reviews have been made of the presence of pesticides in Mexico, mainly from the group of organochlorines in coastal organisms [10] and the national situation of these compounds, including aspects of the use and effects of these compounds both in the environment and in health, concluding that there is a lot of information on organochlorine pesticides in coastal ecosystems and that there is a lack of data on other groups of pesticides such as organophosphates in these coastal sites despite being the most sold compounds in the Mexican territory; in addition, it has been reported that the most commonly used active ingredients are Chlorpyrifos, Methamidophos and Parathion-methyl belonging to this chemical group [11]; derived from this panorama, the purpose of this paper is, therefore, to provide the initial data on the content of organophosphate pesticides in sediments of the Ramsar site Alvarado lagoon at the Gulf of Mexico as a first approach to the presence of these agrochemicals and the potential risk they represent to the benthic community, to contribute with recent information that allows modifying the current legislation and to restrict or prohibit the pesticides considered highly hazardous by diverse international agencies [12] [13] [14].

\section{Study Area}

The geographic coordinates of the Alvarado lagoon are: $18^{\circ} 43^{\prime} 51^{\prime \prime}$ and $18^{\circ} 52^{\prime} 40^{\prime \prime} \mathrm{N}$ - 
$95^{\circ} 42^{\prime} 23^{\prime \prime}$ and $95^{\circ} 57^{\prime} 25^{\prime \prime} \mathrm{W}$, with an area of $4452.5 \mathrm{ha}$, and a maximum depth of $2.6 \mathrm{~m}$. It connects with the Gulf of Mexico through a marine mouth and a 0.4 $\mathrm{km}$ wide barrier. The great Alvarado Lagoon System (SLA for its initials in Spanish) is constituted by interconnected lagoons as Buen País and Camaronera and large number of interior lagoons like Tlalixcoyan, among others; and the Blanco, Camarón, Acula, Palma Real and Papaloapan rivers (Figure 1). This system was designated Ramsar Site number 1355 in 2004, in the International Important Wetland category. Sediments are dominantly silty with clays, poor in organic matter and carbonates, less than $2 \%$, and between $1 \%$ and $7 \%$, respectively [15]. Near the marine mouth which connects to the sea, the sand can reach up to $50 \%$. The edge of the lagoons is dominated by red mangroves, and the ecosystem harbors endangered species such as the manatee and certain threatened migratory birds [16].

\section{Materials and Methods}

Samples of surface sediments were collected using a van Veen dredge to obtain the first $5 \mathrm{~cm}$ of the sedimentary column in 10 lagoon sites (Figure 1) in March 2016, which corresponds to the transition from the northern winds to the dry season, the temperature of the samples remaining at $4^{\circ} \mathrm{C}$ until they were analyzed in the laboratory. Sediment extraction was done with an Anton Paar 3000 microwave equipment according to the Environmental Protection Agency 3546 method with a hexane:acetone mixture 1:1 v/v. The extract was cleaned as indicated in the Environmental Protection Agency 3620C method using Florisil and an elution sequence of the mixture ethyl-ether in hexane at $6 \%, 15 \%, 50 \%$ and $100 \%$ to obtain four fractions and a recovery percentage between $80 \%$ and $100 \%$. 1-Bromo-2nitrobenzene was used as internal standard $(50 \mathrm{pg} / \mu \mathrm{L})$, the final analysis was done with a gas chromatograph coupled to an Agilent Technologies (6890) mass spectrometer, with an automatic injector and quadrupole with negative chemical ionization (5973N) and a DB-35MS capillary column $(60 \mathrm{~m} \times$ $0.25 \mathrm{~mm} \times 0.25 \mu \mathrm{m}$ ). The carrier gas was helium grade 5.0 with a $1 \mathrm{ml} / \mathrm{min}$ flow rate. For quality control we analyzed, blank reactive, reference material and fortified samples. Detection limits are shown in Table 1 , found in $<0.4 \mathrm{pg} / \mu \mathrm{L}$ interval for Diazinon to $<8.3 \mathrm{pg} / \mu \mathrm{L}$ for Dimethoate.

\section{Results and Discussion}

Table 1 shows the results of the sediment analysis in which 12 organophosphate pesticides were determined. We obtained data above the detection limits of only five compounds: Chlorpyrifos, Chlorpyrifos methyl, Dimethoate, Ethion and Fenchlorphos, or $41.7 \%$ of the xenobiotics we were looking for. The total concentration of the quantified OPs had a maximum value of 79,824.4 pg/g in site 9, and site 10 had a similar value $(79,265.5 \mathrm{pg} / \mathrm{g})$ since both sampling points are near the village and Port of Alvarado which are directly influenced by the Gulf of Mexico through the area where both bodies of water join (Figure 1). The total 


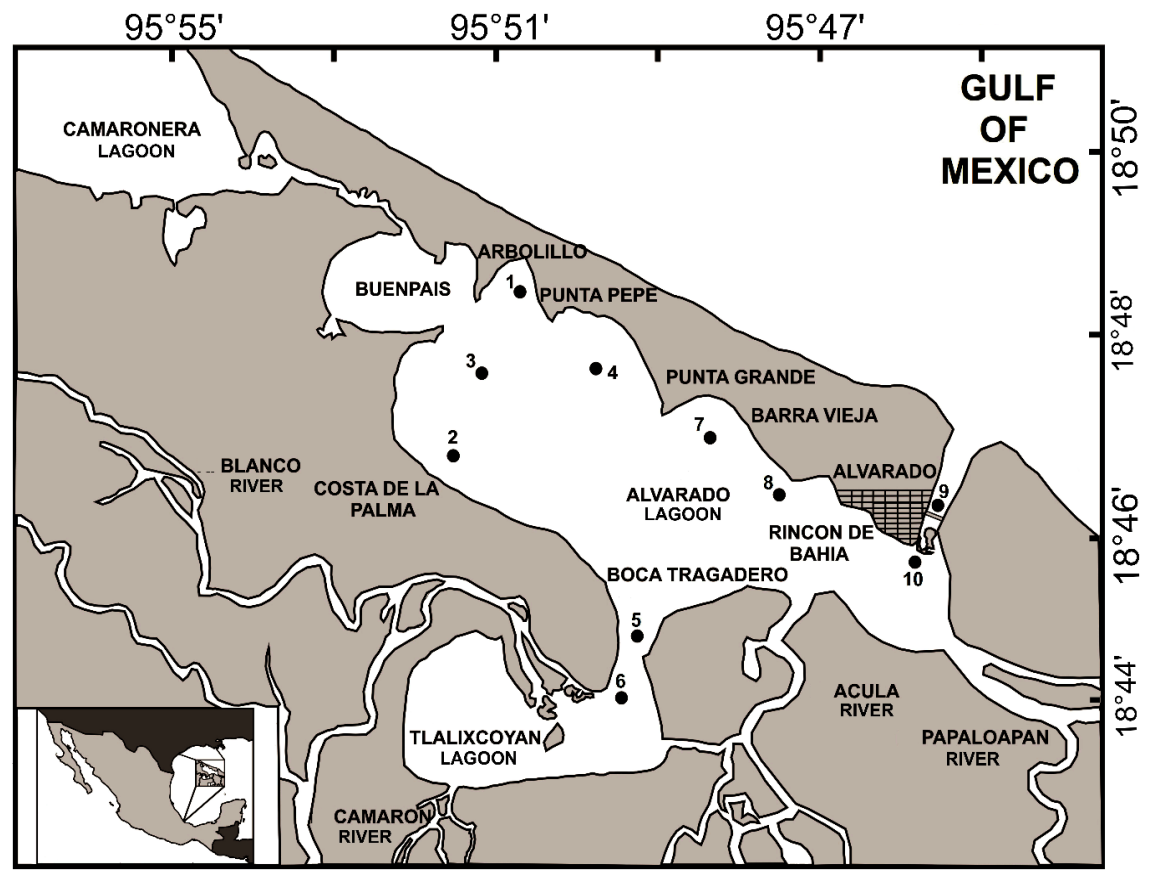

Figure 1. Study area and sampling sites in Alvardo lagoon, Gulf of Mexico.

Table 1. Concentration in $\mathrm{pg} / \mathrm{g}$ dry weight of organophosphate pesticides in sampling sites of surface sediments in the Alvarado lagoon, mean \pm standard deviation and physical and chemical properties related to the environmental persistence of organophosphate pesticides; the organochlorine $p, p^{\prime}$-DDT is used as reference.

\begin{tabular}{|c|c|c|c|c|c|c|c|c|c|c|c|c|c|c|}
\hline & & & & amplin & sites of & surface & sedimer & & & & & & & \\
\hline $\begin{array}{l}\text { Organophosphate } \\
\text { pesticides (OPs) }\end{array}$ & 1 & 2 & 3 & 4 & 5 & 6 & 7 & 8 & 9 & 10 & Mean \pm SD & $\begin{array}{c}\text { Molecular } \\
\text { weight }\end{array}$ & $\log K_{o w}$ & $\begin{array}{c}\text { Water } \\
\text { solubility } \\
(\mathrm{mg} / \mathrm{L})\end{array}$ \\
\hline Chlorpyrifos & 203.8 & 215.0 & 167.8 & 165.4 & 199.6 & 207.4 & 224.0 & 209.4 & 225.5 & 195.7 & $201.4 \pm 20.7$ & 350.6 & $4.5-5.3$ & $0.3-1.4$ \\
\hline Chlorpyrifos methyl & $<2.0^{*}$ & $<2.0^{*}$ & $<2.0^{*}$ & $<2.0^{*}$ & $<2.0^{*}$ & $<2.0^{*}$ & $<2.0^{*}$ & $<2.0^{*}$ & 43.9 & $<2.0$ & $<\mathrm{LOD}$ & 322.5 & 4.3 & 4.0 \\
\hline Diazinon & $<0.4^{\star}$ & $<0.4^{\star}$ & $<0.4^{*}$ & $<0.4^{\star}$ & $<0.4^{*}$ & $<0.4^{*}$ & $<0.4^{*}$ & $<0.4^{*}$ & $<0.4$ & $<0.4$ & $<$ LOD & 304.3 & 3.8 & $<1.0$ \\
\hline Dimethoate & $<8.3^{*}$ & $<8.3^{*}$ & $<8.3^{*}$ & $<8.3^{*}$ & $<8.3^{*}$ & $<8.3^{*}$ & $<8.3^{*}$ & $<8.3^{*}$ & $78,999.6$ & $78,651.7$ & $78,825.7 \pm 246.0$ & 229.2 & 0.8 & $1-10.0$ \\
\hline Dioxanthion & $<1.0^{*}$ & $<1.0^{*}$ & $<1.0^{*}$ & $<1.0^{*}$ & $<1.0^{*}$ & $<1.0^{*}$ & $<1.0^{*}$ & $<1.0^{*}$ & $<1.0^{*}$ & $<1.0^{*}$ & $<$ LOD & 456.5 & 3.0 & $<0.1$ \\
\hline${ }^{\mathrm{a}} \mathrm{EPN}$ & $<7.4^{\star}$ & $<7.4^{\star}$ & $<7.4^{*}$ & $<7.4^{\star}$ & $<7.4^{*}$ & $<7.4^{*}$ & $<7.4^{*}$ & $<7.4^{*}$ & $<7.4^{*}$ & $<7.4^{*}$ & $<$ LOD & 323.3 & 4.8 & Insoluble \\
\hline Fenchlorphos & 48.9 & 28.0 & 31.0 & 38.9 & $<0.3^{*}$ & $<0.3^{*}$ & 36.8 & $<0.3^{*}$ & $<0.3^{*}$ & $<0.3^{*}$ & $36.7 \pm 8.1$ & 321.5 & 5.1 & 1.0 \\
\hline Malathion & $<6.6^{*}$ & $<6.6^{*}$ & $<6.6^{*}$ & $<6.6^{*}$ & $<6.6^{*}$ & $<6.6^{*}$ & $<6.6^{*}$ & $<6.6^{*}$ & $<6.6^{*}$ & $<6.6^{*}$ & $<\mathrm{LOD}$ & 330.3 & 2.4 & 143.0 \\
\hline Parathion & $<2.2^{\star}$ & $<2.2^{\star}$ & $<2.2^{*}$ & $<2.2^{\star}$ & $<2.2^{\star}$ & $<2.2^{*}$ & $<2.2^{\star}$ & $<2.2^{\star}$ & $<2.2^{*}$ & $<2.2^{*}$ & $<$ LOD & 291.2 & 3.8 & 11.0 \\
\hline Parathion methyl & $<1.8^{\star}$ & $<1.8^{*}$ & $<1.8^{*}$ & $<1.8^{\star}$ & $<1.8^{*}$ & $<1.8^{*}$ & $<1.8^{*}$ & $<1.8^{*}$ & $<1.8^{*}$ & $<1.8^{*}$ & $<$ LOD & 263.2 & 2.9 & 37.7 \\
\hline Terbufos & $<0.5^{\star}$ & $<0.5^{\star}$ & $<0.5^{*}$ & $<0.5^{\star}$ & $<0.5^{\star}$ & $<0.5^{*}$ & $<0.5^{\star}$ & $<0.5^{*}$ & $<0.5^{*}$ & $<0.5^{\star}$ & $<$ LOD & 288.4 & 4.5 & 5.1 \\
\hline ¿OPs & 252.7 & 243.0 & 198.8 & 204.3 & 199.6 & 207.4 & 260.8 & 209.4 & $79,824.4$ & $79,265.5$ & $16,086.6 \pm 33,445.8$ & NR & NR & NR \\
\hline $\begin{array}{l}p, p^{\prime} \text {-DDT } \\
\text { (organochlorine } \\
\text { pesticide) }\end{array}$ & & & & & & & & & & & & 354.5 & $6.4-6.9$ & Insoluble \\
\hline
\end{tabular}

${ }^{*}$ Detection limits (LOD) (pg/ $\left.\mu \mathrm{L}\right) ;{ }^{\text {a }} \mathrm{EPN}$ (Ethyl p-nitrophenyl benzenethiophosphonate); NR: Not Reported. 
concentrations of stations 7, 1, 2, in descending order, were 260.8, 252.7 and $243.0 \mathrm{pg} / \mathrm{g}$ respectively, followed by sites 4,6 and 8 with contents between 204 and $209 \mathrm{pg} / \mathrm{g}$ and finally, stations 3 and 5 with levels between 198 and $199 \mathrm{pg} / \mathrm{g}$. Except for the maximum contents of points 9 and 10, the results determined in the rest of the analyzed sediments at the level of total concentration had a comparable magnitude between 198.8 and $260.8 \mathrm{pg} / \mathrm{g}$ which would mean that these agrochemicals are used in the surrounding areas of the lagoon, and that the urban and agricultural area of Alvarado is the main pollutant source which explains the high records found.

One of the few phosphorus compounds reliably quantified was Chlorpyrifos, which was determined in all samples and had a concentration range between 165.4 (station 4) and 225.5 (station 9) pg/g; its methylated form was only detected in site 9 with a content bellow ( $43.9 \mathrm{pg} / \mathrm{g}$ ). Dimethoate was exclusive of the sediments of the marine interaction zone (stations 9 and 10) with the maximum values already mentioned ( $>7000 \mathrm{pg} / \mathrm{g}$ ) same as Ethion, with unique concentrations in these sampling stations, with levels of 555.4 and $418.1 \mathrm{pg} / \mathrm{g}$ respectively. The last organophosphate pesticide found in the sedimentary matrix of the Alvarado lagoon was the Fenchlorphos in sites 1 to 4 and 7, with contents ranging from 28.0 (station 2) to 48.9 (station 1) pg/g. It is important to highlight the absence of this compound in the area inside the Tlalixcoyan lagoon (stations 5 and 6), as well as in the region of Port of Alvarado and the lagoon marine mouth (sites 8, 9 and 10) (Figure 1 and Figure 2).

Some of the main physicochemical characteristics of the evaluated molecules provide information on their degree of persistence. Table 1 compares the molecular weights, the partition coefficient octanol-water $\left(\log \mathrm{K}_{\mathrm{ow}}\right.$ ) and the aqueous solubility of the organophosphates discussed in this paper, and a classical organochlorine, $p$, $p^{\prime}$-DDT. The solubility in water and the lipophilicity capacity are determinant for the permanence or degradation/biogeochemical transformation of pesticides in the environment, in such a way that, considering the behavior of DDT that has been studied since the mid-20th century up to the present day, its environmental persistence has been scientifically documented between 20 and 30 years.

As can be seen, Dimethoate has a $\log \mathrm{K}_{\mathrm{ow}}<1$ and can be considered the least persistent of the group of evaluated organophosphates. Malathion and Parathion-methyl with $\log \mathrm{K}_{\mathrm{ow}}<3$ would follow, contrasting with the environmental behavior of Chlorpyrifos, Ethion, EPN and Fenchlorphos, since their octanol-water partition coefficient is between 4.8 and 5.27 as well as their aqueous solubility, with values from insoluble to $2 \mathrm{mg} / \mathrm{L}$, and it is these molecular characteristics that could favor their permanence for longer periods of time in the environmental matrixes, resulting high degree of persistence at the sediment with harmful effects on the benthic community.

In Mexico there is no established regulation that mentions the highest allowed limits of pollutants in coastal and marine sediments. In the case of pesticides, the 


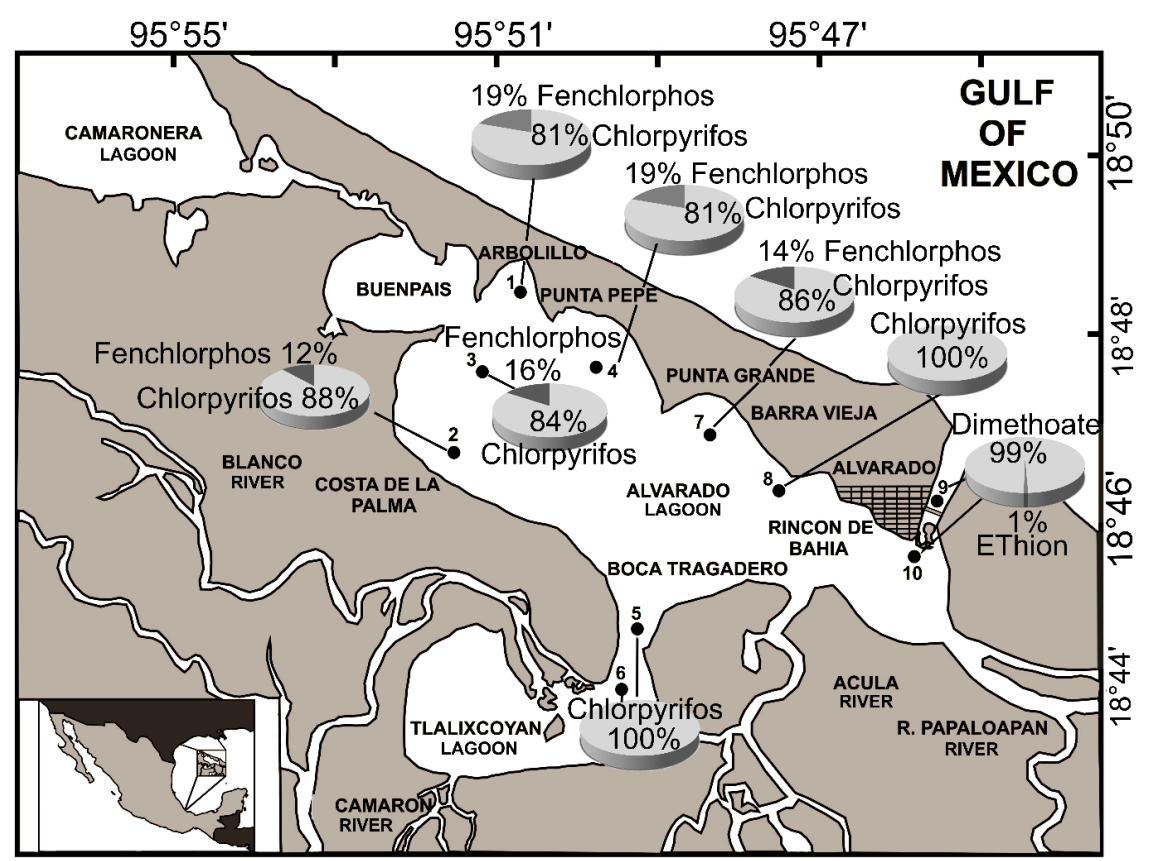

Figure 2. Individual molecular pattern of organophosphate pesticides in sediments of the Alvarado lagoon.

2016 Official Pesticide Catalog, issued by the Federal Commission for the Protection against Sanitary Risks (COFEPRIS for its initials in Spanish), an entity subordinated to the Ministry of Health, should be considered [17]. This Catalog indicates that the authorized pesticides in Mexico are those registered before this Ministry and included in this Catalog. It should be noted that the Catalog `s last update took place after twelve years without government information regarding the registration of these agrochemicals that are distributed, marketed and used in the country, as the previous version dates from 2004. The Catalog does not include the organophosphate pesticides Dioxathion, EPN, Fenchlorphos and Parathion, and it only considers Parathion-methyl. Of the remaining pesticides, it only includes basic physicochemical information, general uses, environmental and health effects, toxicity, risks, first aid and use and management recommendations. Table 2 shows the most relevant Mexican information found in the 2016 Official Pesticide Catalog regarding the xenobiotics dealt with in this study. The acute toxicological category is one of the main criteria and can be compared internationally since it is consistent with the Global Harmonized System (GHS) to weigh the risks derived from the presence and quantity of certain pesticides as consider in a standardize Official Mexican Standard [18].

Terbufos is category 1 since its median lethal dose $\left(\mathrm{LD}_{50}\right)$, ingested orally by rats as test animals, is $1.3 \mathrm{mg} / \mathrm{kg}$, and dermally, by rabbits, is $0.87 \mathrm{mg} / \mathrm{kg}$, it is therefore classified as extremely hazardous, belonging to the class Ia according to the World Health Organization classification [14]. This pesticide, in the sediments of the Alvarado lagoon, was found to be below the analytical detection limit $(<0.5 \mathrm{pg} / \mu \mathrm{L})$. In general terms, the uses established in the official Mexican 
Table 2. Uses, lethal dose $50 \%\left(\mathrm{LD}_{50}\right.$ acute toxicity), environmental effects and guide concentrations of environmental quality issued by NOAA for some organophosphate pesticides (OPs) evaluated in this study [17] [19].

\begin{tabular}{|c|c|c|c|c|c|c|c|c|c|c|c|}
\hline \multirow{3}{*}{ Pesticides } & \multirow{3}{*}{ Uses } & \multirow{3}{*}{$\begin{array}{c}\mathrm{LD}_{50} \\
(\mathrm{mg} / \mathrm{kg})\end{array}$} & \multirow{3}{*}{$\begin{array}{l}\text { Acute } \\
\text { toxicologic } \\
\text { category }\end{array}$} & \multirow{3}{*}{$\begin{array}{l}\text { Effects on the } \\
\text { environment }\end{array}$} & \multirow{3}{*}{$\begin{array}{c}\text { Ground } \\
\text { water }(\mu \mathrm{g} / \mathrm{L})\end{array}$} & \multicolumn{4}{|c|}{ Surface waters $(\mu g / L)$} & \multirow{3}{*}{$\begin{array}{c}\text { Marine } \\
\text { sediments } \\
(\mathrm{ng} / \mathrm{g})\end{array}$} & \multirow{3}{*}{$\begin{array}{l}\text { Soils } \\
\text { (ng/g) }\end{array}$} \\
\hline & & & & & & \multicolumn{2}{|c|}{ Fresh } & \multicolumn{2}{|c|}{ Marine } & & \\
\hline & & & & & & Acute & Chronic & Acute & Chronic & & \\
\hline $\begin{array}{l}\text { Chlorpyrifos } \\
\text { (ethyl and } \\
\text { methyl) }\end{array}$ & $\begin{array}{l}\text { Agricultural, } \\
\text { domestic, } \\
\text { cattle-ranching, } \\
\text { urban, industrial }\end{array}$ & $\begin{array}{c}96 \text { (Rats/oral) } \\
>2000 \text { (rats/ } \\
\text { dermal) }\end{array}$ & 3 & $\begin{array}{l}\text { Very toxic to fish, } \\
\text { birds and bees }\end{array}$ & 30.0 & $0.083^{\mathrm{a}}$ & $0.041^{\mathrm{a}}$ & $0.011^{\mathrm{a}}$ & $0.0056^{\mathrm{a}}$ & NR & NR \\
\hline Diazinon & $\begin{array}{l}\text { Agricultural, } \\
\text { domestic, } \\
\text { cattle-ranching, } \\
\text { urban, industrial, } \\
\text { gardening }\end{array}$ & $\begin{array}{c}1250(\text { Rats/oral }) \\
>2020 \text { (rabbit/ } \\
\text { dermal })\end{array}$ & 4 & $\begin{array}{l}\text { Highly toxic to birds, } \\
\text { fish and bees }\end{array}$ & 20.0 & 0.17 & 0.17 & 0.82 & 0.82 & 1.9 & NR \\
\hline Dimethoate & $\begin{array}{l}\text { Agricultural, } \\
\text { gardening, } \\
\text { industrial }\end{array}$ & $\begin{array}{c}235 \text { (Rats/oral) } \\
>400 \text { (rats/ } \\
\text { dermal) }\end{array}$ & 3 & $\begin{array}{l}\text { Moderate to high } \\
\text { Toxicity to aquatic } \\
\text { organisms and birds. } \\
\text { Extremely toxic } \\
\text { to bees }\end{array}$ & 6.0 & NR & $\begin{array}{c}6.2 \mathrm{CA} \\
0.15 \mathrm{NZ}\end{array}$ & NR & NR & NR & $218.0 \mathrm{M}$ \\
\hline Dioxathion & $\begin{array}{l}\text { Agricultural, } \\
\text { cattle-ranching, } \\
\text { domestic, } \\
\text { gardening, } \\
\text { urban, industrial }\end{array}$ & $\begin{array}{c}23-64 \\
\text { (Rats/oral) }\end{array}$ & 2 & $\begin{array}{c}\text { Very toxic to aquatic } \\
\text { organisms }\end{array}$ & NR & NR & NR & NR & NR & NR & NR \\
\hline EPN & $\begin{array}{l}\text { Agricultural, } \\
\text { cattle-ranching, } \\
\text { domestic, } \\
\text { gardening, } \\
\text { urban, industrial }\end{array}$ & $\begin{array}{c}17.8 \text { (Rats/oral) } \\
30 \text { (rabbit/ } \\
\text { dermal) }\end{array}$ & 2 & $\begin{array}{c}\text { Very toxic to aquatic } \\
\text { organisms }\end{array}$ & NR & NR & NR & NR & NR & NR & NR \\
\hline Ethion & $\begin{array}{l}\text { Agricultural, } \\
\text { cattle-ranching }\end{array}$ & $\begin{array}{c}21 \text { (Rats/oral) } \\
838 \text { (rabbit/ } \\
\text { dermal) }\end{array}$ & 2 & $\begin{array}{l}\text { Highly toxic to fish } \\
\text { and birds. Not toxic } \\
\text { to bees }\end{array}$ & NR & NR & NR & NR & NR & NR & NR \\
\hline Fenchlorphos & $\begin{array}{l}\text { Agricultural, } \\
\text { gardening }\end{array}$ & $\begin{array}{c}1250 \text { (Rats/oral) } \\
1000-2000 \\
\text { (rabbits/ } \\
\text { dermal) }\end{array}$ & 4 & $\begin{array}{l}\text { Very toxic to aquatic } \\
\text { organisms }\end{array}$ & NR & NR & NR & NR & NR & NR & NR \\
\hline Malathion & $\begin{array}{l}\text { Agricultural, } \\
\text { cattle-ranching, } \\
\text { gardening, } \\
\text { urban, industrial }\end{array}$ & $\begin{array}{c}5500 \\
(\text { Rats/oral) }> \\
2000 \text { (rabbits/ } \\
\text { dermal) }\end{array}$ & $4-5$ & $\begin{array}{l}\text { Slightly to } \\
\text { extremely toxic to } \\
\text { fish. Moderately } \\
\text { toxic to birds, highly } \\
\text { toxic to bees }\end{array}$ & 190.0 & NR & 0.1 & NR & 0.1 & 0.67 & NR \\
\hline $\begin{array}{l}\text { Parathion } \\
\text { (parathion } \\
\text { methyl) }\end{array}$ & $\begin{array}{l}\text { Agricultural, } \\
\text { industrial }\end{array}$ & $\begin{array}{c}6 \text { (Rats/oral) } 66 \\
(\mathrm{rat} / \mathrm{dermal})\end{array}$ & 2 & $\begin{array}{c}\text { Toxic to aquatic and } \\
\text { terrestrial } \\
\text { organisms }\end{array}$ & $50.0^{\mathrm{b}}$ & NR & $0.065^{\mathrm{b}}$ & $0.013^{\mathrm{b}}$ & NR & NR & $0.34 \mathrm{~V}$ \\
\hline Terbufos & Agricultural & $\begin{array}{l}1.3 \text { (Rats/oral) } \\
0.87 \text { (rabbits/ } \\
\text { dermal) }\end{array}$ & 1 & $\begin{array}{l}\text { Extremely toxic to } \\
\text { birds, mammals, } \\
\text { reptiles, fish and } \\
\text { other aquatic } \\
\text { organisms }\end{array}$ & NR & NR & NR & NR & NR & NR & NR \\
\hline
\end{tabular}

a only for Chlorpyrifos; 'bonly for Parathion; NR: Not Reported; CA: Canadian Water Quality Guidelines; NZ: quality criteria for epicontinental waters in Australia and New Zealand; M: Toxicity towards mammals; V: Toxicity towards plants.

document for this group of pesticides are the same, from the agricultural to the industrial, including domestic and gardening uses. Likewise, the qualitative description of its toxicity indicates a gradient going from slightly toxic for fish (Malathion), to extremely toxic for bees, birds, fish and mammals (Dimethoate 
and Terbufos) [17].

Regarding the compounds detected in this study, for Chlorpyrifos in its ethyl and methyl forms, the Mexican Catalog reports oral and dermal $\mathrm{LD}_{50}$ of 96 and $>2000 \mathrm{mg} / \mathrm{kg}$ and classifies it as acute toxicological category 3, while WHO includes it in the group of moderately hazardous (class II), being very toxic for bees, birds and fish. Dimethoate has a lower number of established uses, being and authorized for agricultural, industrial and landscaping purposes, not for domestic and livestock related uses, with a toxicity classification of 3, moderately hazardous like Chlorpyrifos, with different $\mathrm{LD}_{50}, 235$ and $>400 \mathrm{mg} / \mathrm{kg}$ for oral and dermal intake in rats, respectively.

The Pesticide Official Catalog of Mexico establishes two uses for Ethion, agricultural and livestock-related, belonging to group 2 due to its acute toxicity, with $\mathrm{LD}_{50}$ of 21 and $838 \mathrm{mg} / \mathrm{kg}$ in tests, oral in rats and dermal in rabbits, and highly toxic for fish and birds, but not for bees. Fenclorfos has few registered uses, mainly in agriculture and gardening, with median lethal dose of $1250 \mathrm{mg} / \mathrm{kg}$ orally in rats, and $1000-2000 \mathrm{mg} / \mathrm{kg}$ dermally in rabbits; it belongs to highly toxic category 4 , very toxic to aquatic organisms (Table 2).

Even though we did not quantify levels above the limits of detection in most of the organophosphate pesticides in the lagoon, it is important to mention the discrepancies regarding the acute toxicity and the danger of classifying these compounds considering what has been established in a standardize [17], which is included in the 2016 Mexican Pesticide Official Catalog, and the 2009 WHO classification. For example, EPN, Parathion and Parathion-methyl are cataloged in the class that groups the extremely hazardous pesticides [14] while the national document places them in category 2. Chlorpyrifos, Dimethoate, Diazinon and Ethion belong to class II of WHO, classified as moderately hazardous, while in Mexico, the first two are placed in the toxicological category 3, the third one in category 4 , and the last in category 2 , which highlights the variability that can occur depending on the reference criteria considered and, therefore, the actions or restrictions that may be established for their general management and/or their definitive ban.

Another fundamental aspect affecting the presence, accumulation and effects of these and other pesticides in Mexican ecosystems-including coastal ones such as the Alvarado lagoon-is the number of commercial entities with official records from the COFEPRIS for their distribution and use. In Annex 2 of the 2016 Official Pesticide Catalog there are, for Chlorpyrifos only its ethyl and methyl forms, 171 records out of a total of 5524 (3.1\%), most of indeterminate validity, which allows their continuous use. Dimethoate has 79 records (1.4\%) all of them with no expiration date. For Ethion there are only eight registers $(0.14 \%)$ and, just as in the previous cases, with indeterminate validity. Officially, these three pesticides have an insecticide-acaricide use. It is worth mentioning that Fenchlorphos, found in this study, is not registered with COFEPRIS, which means it is not authorized in Mexico [17].

Thanks to scientific efforts of the highest quality, mainly from developed 
countries both in America and Europe, there are today environmental quality criteria for diverse ecosystem matrixes whose purpose is to provide reference of contaminant concentrations which can damage water, sediments and soil. The National Oceanic and Atmospheric Administration of the American Department of Commerce in the USA (NOAA), has gathered all this information and created the well-known Screening Quick Reference Tables or SQuiRTs [19], that allow to weigh the magnitude of the concentrations registered in the various compartments of the ecosystems under study in the absence of a complete, consistent and comparable global environmental regulation.

For most of the organophosphate pesticides found in this study there is no ecotoxicological reference data from NOAA for marine sediments; however, we consider that it is important to present guide concentrations of possible effects established for groundwater, continental and marine surface water, soils and the average lethal dose (acute and chronic toxicity) that this environmental agency has available from some OPs analyzed in this work. These criterion concentrations are presented in Table 2 and it can be observed that the threshold concentrations in marine sediments of Diazinon and Malathion to cause harmful effects in the benthos are 1.9 and $0.67 \mathrm{ng} / \mathrm{g}$, respectively. For Chlorpyrifos, the highest level of contamination in groundwater is $30 \mu \mathrm{g} / \mathrm{L}$, established by the US Environmental Protection Agency (USEPA), even used in Canada for sources of drinking water, like WHO. In epicontinental waters, concentrations of this same organophosphorus that cause acute and chronic risk have been estimated at 0.083 and $0.041 \mu \mathrm{g} / \mathrm{L}$, respectively, and in seawater they vary from 0.011 to $0.0056 \mu \mathrm{g} / \mathrm{L}$ respectively, causing acute and chronic conditions (Table 2).

In studies of this nature, with not much background information on records of these pesticides, we need to compare our results with others from similar coastal environments with similar problems caused by the intensive use of these agrochemicals. Table 3 shows a compilation of recently published data on the presence of some OPs in river, lacustrine and lagoon sediments. In general, there are few papers reporting the $\Sigma$ OPs and, in this case, data of this study can be compared with those of the Guan River in China [20] and with the estuary of the Tiber River in Italy (one of the 20 longest rivers in Italy and most polluted) [2], not a pleasant fact when compared to data from the Alvarado lagoon.

Within the specific framework of individual organophosphate compounds, Chlorpyrifos is the pesticide with more data to compare; concentrations found in this study were similar to the lowest reported ranges in sediments of the Zigo River in Togo, Africa [21], of the Guadalquivir and Llobregat rivers in Spain [22] [23] and the already mentioned Tiber River in Italy [2]. Another OP included in this comparison is Dimethoate, not detected in sediments of the African river, nor in the Spanish rivers Llobregat-Anoia, Turia-Jucar [24] [25] or the Tiber, remarkably contrasting with the concentrations in the Alvarado lagoon, which were high (78 - $79 \mathrm{ng} / \mathrm{g})$. In addition, other OP like Diazinon and Malathion were checked, but they were not detected during this study $(<0.4$ and $<6.6 \mathrm{pg} / \mu \mathrm{L}$, respectively) although the first of these was found in sediments of Zumpango 
Table 3. Comparison of the concentrations of organophosphate pesticides in sediments of several coastal areas of the world. Values in $\mathrm{ng} / \mathrm{g}$ dry weight.

\begin{tabular}{|c|c|c|c|c|c|c|}
\hline Area & $\Sigma O P s$ & Chlorpyrifos & Dimethoate & Diazinon & Malathion & Reference \\
\hline \multicolumn{7}{|l|}{ Africa } \\
\hline Zigo River, Togo & & $0.82-26.93$ & ND & ND & ND & {$[21]$} \\
\hline \multicolumn{7}{|l|}{ Asia } \\
\hline Guan River, China & $0.0-2.18$ & & & & & [20] \\
\hline \multicolumn{7}{|l|}{ America } \\
\hline Zumpango Lake, Mexico & & 5120.0 & & 110.0 & & [26] \\
\hline \multicolumn{7}{|l|}{ Europa } \\
\hline Portuguese rivers & & & & $11.5-19.2$ & & {$[4]$} \\
\hline Arc River, France & & $0.01-0.02$ & & & & [30] \\
\hline Guadalquivir River, Spain & & $0.7-15.9$ & & $0.2-175.5$ & & {$[22]$} \\
\hline \multicolumn{7}{|l|}{ Mediterranean Sea } \\
\hline Damietta Channel, Egypt & & 303.8 & & 279.0 & 5.12 & [27] \\
\hline Llobregat \& Anoia rivers, Spain & & & ND & $0.09-1.29$ & ND & [24] \\
\hline Llobregat River, Spain & & $0.39-130.97$ & & $0.04-2.53$ & & [23] \\
\hline Berre Lagoon, France & & ND & & & & {$[31]$} \\
\hline Turia \& Jucar rivers, Spain & & $4.51-55.95$ & ND & ND & ND & [25] \\
\hline Tiber River, Italy & $1.42-68.5$ & $0.26-32.85$ & ND & $0.18-0.54$ & ND & {$[2]$} \\
\hline Alvarado Lagoon, Mexico & $0.2-79.8$ & $0.17-0.23$ & $78.7-79.0$ & ND & ND & This study \\
\hline
\end{tabular}

ND: Not Detected $(<$ LOD).

Lake, Estado de Mexico, with $110 \mathrm{ng} / \mathrm{g}$ [26] and in marine sediments of the Damietta Canal in Egypt, 279 ng/g [27]. Regarding Malathion, there is only piece of information corresponding to the area of the Egyptian channel, a concentration of $5.12 \mathrm{ng} / \mathrm{g}$ (Table 3 ).

The insecticide Dimethoate inhibits the acetylcholinesterase enzyme which causes the accumulation of the neurotransmitter acetylcholine and increases the cholinergic synapse. The effect of this organophosphate is similar in insects and mammals, the main difference being the way it is eliminated, as mammals are more efficient eliminating it through urine (87\% - 90\%) [28] [29]. Crustaceans like shrimp and crabs, important elements in the ecology and economy of coastal ecosystems in the Gulf of Mexico, are likely to be affected by OPs since they are similar to insects, the target of these biocides, as they are part of the same large biological group, the arthropods.

Organophosphate pesticides are found in the complex assembly of agrochemicals in coastal sediments; here, organochlorines and pollutants of industrial origin like the polychlorinated biphenyls, can cause a combined exposure from the intrinsic sedimentary toxicity involving unknown or poorly documented interactions causing high impact damage [2]. In recent years, these types of sub- 
stances have been studied to learn more about their acute and chronic effects and there is sufficient evidence to classify them as toxic to aquatic organisms, as well as to birds, and their effect on bees and other pollinators has now been analyzed [32].

This information is a first approach to the presence of OPs in sediments of the Alvarado lagoon; there are many studies from this coastal area of the Gulf of Mexico regarding biological, geological, fishing, hydrodynamic, socioeconomic and, to a lesser extent, environmental factors, that focus mainly on metals, sanitary microbiology, organochlorine pesticides, water quality, change in geochemical signals of sedimentary accumulation due to important historical modifications in the basin, among others [7] [8] [15] [33] [34] [35]. Our study, therefore, constitutes one of the first ones recording the presence of OPs. These semi-persistent compounds can come largely from the urban area of the Port of Alvarado. In addition, there is an important contribution from the Blanco, Limón and Papaloapan rivers due to the transport of agrochemicals from the fields in their more than $200 \mathrm{~km}$ of route from their origin to the Gulf of Mexico; these rivers pick up diverse dissolved and suspended substances when crossing large agricultural [36] and industrial areas, and then pour their water into this lagoon which then becomes; on the one hand, a coastal reservoir of substances and materials necessary for the right ecological processes with nutrients and good quality organic matter and, on the other, of xenobiotics of high risk to the environment and to human health such as the organophosphates [9] [37].

\section{Conclusion}

Five organophosphate pesticides were recorded in the sediments of the Alvarado lagoon. Chlorpyrifos was recorded in all analyzed sites, with low concentrations when compared to reports from several coastal environments around the world. Fenchlorphos was recorded in half of the analyzed samples, mainly in the central-northern region of the study area. Ethion and Dimethoate were registered in the influence area in the Port of Alvarado in connection with the Gulf of Mexico. Our study found that Dimethoate was the organophosphate compound with the highest concentration, with levels like those reported for polluted rivers that discharged into the Mediterranean Sea and this represented a high risk for benthos. Therefore, it can be classified to the Laguna de Alvarado, in particular to the area under the influence of the Port of Alvarado, as a hot spot site by organophosphate pesticides. The presence of these compounds in sediments constitutes scientific evidence of the impact of human settlements and their activities such as agriculture and livestock around the study area reaches it mainly through river runoff. These pesticides are used to control vectors, such as insect pests in order to avoid health problems from tropical diseases such as malaria and dengue fever, despite the risk of chemical contamination to the benthic organisms and long-term ecological disturbances on this biological community of great relevance to coastal ecosystems. Without enough studies of this type, there 
is not enough reliable data to define more effective control policies, with less environmental and human health consequences.

\section{Acknowledgements}

The authors wish to thank Salvador Hernández Pulido, academic technician, for elaborate the figures 1 and 2 that correspond to the study area with sampling sites, and distribution concentration of organophosphate pesticides at Alvarado lagoon, respectively and by correctly ordering the references in the text and in the corresponding section.

\section{Funding}

Funding was provided by Instituto de Biología, Universidad Nacional Autónoma de México, México Project 602 Alvarado Lagoon.

\section{Conflicts of Interest}

The authors declare no conflicts of interest regarding the publication of this paper.

\section{References}

[1] Singh, B. and Walker, A. (2006) Microbial Degradation of Organophosphorus Compounds. Microbiology Reviews, 30, 428-471.

[2] Montuori, P., Aurino, S., Garzonio, F., Sarnacchiaro, P., Polichetti, S., Nardone, A. and Triassi, M. (2016) Estimates of Tiber River Organophosphate Pesticide Loads to the Tyrrhenian Sea and Ecological Risk. Science of the Total Environment, 559, 218-231. https://doi.org/10.1016/j.scitotenv.2016.03.156

[3] Kolankaya, D. (2006) Organochlorine Pesticide Residues and Their Toxic Effects on the Environment and Organisms in Turkey. International Journal of Environmental Analytical Chemistry, 86, 147-160. https://doi.org/10.1080/03067310500247918

[4] Villaverde, J., Hildebrandt, A., Martínez, E., Lacorte, S., Morillo, E., Maqueda, C., Viana, P. and Barceló, D. (2008) Priority Pesticides and Their Degradation Products in River Sediments from Portugal. Science of the Total Environment, 390, 507-513. https://doi.org/10.1016/j.scitotenv.2007.10.034

[5] Jegede, O.O., Owojoria, O.J. and Römbke, J. (2017) Temperature Influences the Toxicity of Deltamethrin, Chlorpyrifos and Dimethoate to the Predatory Mite $\mathrm{Hy}^{-}$ poaspis aculeifer (Acari) and the Springtail Folsomia candida (Collembola). Ecotoxicology and Environmental Safety, 140, 214-221.

https://doi.org/10.1016/j.ecoenv.2017.02.046

[6] Carvalho, F.P., Villenueve, J.P., Cattini, C., Rendón, J. and Mota de Oliveira, J. (2009) Pesticide and PCB Residues in the Aquatic Ecosystems of Laguna de Terminos, a Protected Area of the Coast of Campeche, Mexico. Chemosphere, 74, 988-995. https://doi.org/10.1016/j.chemosphere.2008.09.092

[7] Guzmán-Amaya, P., Villanueva, F.S. and Botello, A.V. (2005) Metales en tres lagunas costeras del estado de Veracruz. In: Botello, A.V., Rendón-von-Osten, J., Gold-Bouchot, G. and Agraz-Hernández, C., Eds., 2nd Edition, Golfo de México, Contaminación e Impacto Ambiental: Diagnóstico y Tendencias. Universidad Autónoma de Campeche, Universidad Nacional Autónoma de México, Instituto 
Nacional de Ecología, Universidad Autónoma de Campeche, Universidad Nacional Autónoma de México, Instituto de Ecología. ISBN 968-5722-37-4.361-372.

[8] Palmerín, R.C., Ponce-Vélez, G. and Botello, A.V. (2014) Evaluación de plaguicidasorganoclorados en sedimentos y organismos filtradores de la laguna de Alvarado, Veracruz, México. In: Botello, A.V., Rendón von Osten, J., Benítez, J.A. and Gold-Bouchot, G., Eds., Golfo de México. Contaminación e impacto ambiental: Diagnóstico y Tendencias, Universidad Autónoma de Campeche, Instituto de Ciencias del Mar y Limnología, UNAM, Centro de Investigación y de Estudios Avanzados Unidad Mérida. ISBN 978-607-7887-71-3. 285-308.

[9] Carvalho, F.P., Villeneuve, J.P., Jaime Rendón, Ch.C. and Mota de Oliveira, J. (2009) Ecological Risk Assessment of PCBs and Other Organic Contaminant Residues in Laguna de Terminos, Mexico. Ecotoxicology, 18, 403-416. https://doi.org/10.1007/s10646-008-0295-9

[10] Ponce-Vélez, G. and Botello, A.V. (2018) Plaguicidas organoclorados en organismos costeros y marinos de los litorales mexicanos: Una Revision. Revista Internacional de Contaminación Ambiental, 34, 81-98. https://doi.org/10.20937/RICA.2018.34.esp02.07

[11] García-Hernández, J., Leyva-Morales, J.B., Martínez-Rodríguez, I.E., HernándezOchoa, M.I., Aldana-Madrid, M.L., Rojas-García, A.E., Betancourt-Lozano, M., Pérez-Herrera, N.E. and Perera-Ríos, J.H. (2018) Estado actual de la investigación sobre plaguicidas en México. Revista internacional de contaminación ambiental, 34 , 29-60. https://doi.org/10.20937/RICA.2018.34.esp01.03

[12] Bejarano-González, F. (2017) Los Plaguicidas Altamente Peligrosos en México. Red de Acción sobre Plaguicidas y Alternativas en México, A.C. (RAPAM), 351 p.

[13] Pesticide Action Network International (PAN) (2016) International List of Highly Hazardous Pesticides (PAN List of HHPs). PAN, Hamburg, 35 p.

[14] World Health Organization (WHO) (2009) The WHO Recommended Classification of Pesticides by Hazard and Guidelines to Classification 2009. International Programme on Chemical Safety, 78 p.

[15] Ruiz-Fernández, A.C., Maanan, M, Sanchez-Cabeza, J.A., Hascibe, L., Pérez Bernal, L.H., López Mendoza, P. and Limoges, A. (2014) Cronología de la sedimentación reciente y caracterización geoquímica de los sedimentos de la laguna de Alvarado, Veracruz (suroeste del Golfo de México). Ciencias Marinas, 40, 291-303.

[16] Comisión Nacional de Áreas Naturales protegidas, CONANP (2014) Humedales mexicanos de importancia internacional (sitios RAMSAR).

[17] Comisión Federal para la Protección contra Riesgos Sanitarios, COFEPRIS (2016) Catálogo Oficial de Plaguicidas. Anexos 1 y 2, 50 p.

[18] Norma Oficial Mexicana NOM-232-SSA1-2009, Plaguicidas: Que establece los requisitos del envase, embalaje y etiquetado de productos grado técnico y para uso agrícola, forestal, pecuario, jardinería, urbano, industrial y doméstico. Diario Oficial de la Federación, 13/04/2010.

[19] Buchman, M.F. (2008) National Oceanic and Atmospheric Administration (NOAA) Screening Quick Reference Tables. NOAA OR\&R Report 08-1, Office of Response and Restoration Division, National Oceanic and Atmospheric Administration, Seattle, $34 \mathrm{p}$.

[20] He, X., Song, X., Pang, Y., Li, Y., Chen, B. and Feng, Z. (2014) Distribution, Sources, and Ecological Risk Assessment of SVOCs in Surface Sediments from Guan River Estuary, China. Environmental Monitoring and Assessment, 186, 4001-4012. https://doi.org/10.1007/s10661-014-3675-z 
[21] Mawussi, G., Scorza, J.R.P., Dossa, E.L. and Alaté, K.K. (2014) Insecticide Residues in Soil and Water in Coastal Areas of Vegetable Production in Togo. Environmental Monitoring and Assessment, 186, 7379-7385. http://dx.doi.org/10.1007/s10661-014-3934-z

[22] Masiá, A., Campo, J., Vázquez-Roig, P., Blasco, C. and Picó, Y. (2013) Screening of Currently Used Pesticides in Water, Sediments and Biota of the Guadalquivir River Basin (Spain). Journal of Hazardous Materials, 263, 95-104. https://doi.org/10.1016/j.jhazmat.2013.09.035

[23] Masiá, A., Campo, J., Navarro-Ortega, A., Barceló, D. and Picó, Y. (2015) Pesticide Monitoring in the Basin of Llobregat River (Catalonia, Spain) and Comparison with Historical Data. Science of the Total Environment, 503-504, 58-68. https://doi.org/10.1016/j.scitotenv.2014.06.095

[24] Ricart, M., Guasch, H., Barceló, D., Brix, R., Conceição, M.H., Geiszinger, A., López de Alda, M.J., López-Doval, J.C., Muñoz, I., Postigo, C., Romaní, A.M., Villagrasa, M. and Sabater, S. (2010) Primary and Complex Stressors in Polluted Mediterranean Rivers: Pesticide Effects on Biological Communities. Journal of Hydrology, 383, 52-61. https://doi.org/10.1016/j.jhydrol.2009.08.014

[25] Ccanccapa, A., Masiá, A., Andreu, V. and Picó, Y. (2016) Spatio-Temporal Patterns of Pesticide Residues in the Turia and Júcar Rivers (Spain). Journal Science of the Total Environment, 540, 200-210. https://doi.org/10.1016/j.scitotenv.2015.06.063

[26] Dzul-Caamal, R., Domínguez-López, M.L., Olivares-Rubio, H.F., García-Latorre, E. and Vega-López, A. (2014) The Relationship between the Bioactivation and Detoxification of Diazinon and Chlorpyrifos, and the Inhibition of Acetylcholinesterase Activity in Chirostoma jordani from Three Lakes with Low to High Organophosphate Pesticides Contamination. Ecotoxicology, 23, 779-790.

https://doi.org/10.1007/s10646-014-1216-8

[27] Abdel-Halim, K.Y., Salama, A.K., El-khateeb, E.N. and Bakry, N.M. (2006) Organophosphorus Pollutants (OPP) in Aquatic Environment at Damietta Governorate, Egypt: Implications for Monitoring and Biomarker Responses. Chemosphere, 63, 1491-1498. https://doi.org/10.1016/j.chemosphere.2005.09.019

[28] Blair, A., Ritz, B., Wesseling, C. and Freeman, L. (2014) Pesticides and Human Health. Occupational and Environmental Medicine. http://dx.doi.org/10.1136/oemed-2014-102454

[29] Han, Y., Mo, R., Yuan, X., Zhong, D., Tang, F., Ye, C. and Liu, Y. (2017) Pesticide Residues in Nut-Planted Soils of China and Their Relationship between Nut/Soil. Chemosphere, 180, 42-47. https://doi.org/10.1016/j.chemosphere.2017.03.138

[30] Kanzari, F., Syakti, A.D., Asia, L., Malleret, L., Mille, G., Jamoussi, B., Abderrabba, M. and Doumenq, P. (2012) Aliphatic Hydrocarbons, Polycyclic Aromatic Hydrocarbons, Polychlorinated Biphenyls, Organochlorine, and Organophosphorous Pesticides in Surface Sediments from the Arc River and the Berre Lagoon, France. Environmental Science and Pollution Research International, 19, 559-576. https://doi.org/10.1007/s11356-011-0582-5

[31] Kanzari, F., Asia, L., Syakti, A.D., Piram, A., Malleret, L., Mille, G. and Doumenq, P. (2015) Distribution and Risk Assessment of Hydrocarbons (Aliphatic and PAHs), Polychlorinated Biphenyls (PCBs), and Pesticides in Surface Sediments from an Agricultural River (Durance) and an Industrialized Urban Lagoon (Berre Lagoon), France. Environmental Monitoring and Assessment, 187, 591. https://doi.org/10.1007/s10661-015-4823-9

[32] Boulanouara, S., Mezzachec, S., Combèsa, A. and Pichona, V. (2018) Molecularly 
Imprinted Polymers for the Determination of Organophosphorus Pesticides in Complex Samples. Talanta, 176, 465-478.

https://doi.org/10.1016/j.talanta.2017.08.067

[33] Bello, J., Gómez, L, Magaña, V., Graizbord, B. and Rodríguez, P.H. (2009) Sitio piloto Río Papaloapan-Laguna de Alvarado. In: Buenfil Friedman, J., Ed., Adaptación a los Impactos del Cambio Climático en los Humedales Costeros del Golfo de México. Volumen II. Secretaría de Medio Ambiente y Recursos Naturales/Instituto Nacional de Ecología, México, 435-456.

[34] De la Lanza-Espino, G. and Hernández-Pulido, S. (2017) Natural and Induced Space/Time Environmental Changes in the Teacapan-Agua Brava System, NW México. Journal Aquaculture Marine Biology, 5, 1-6.

https://doi.org/10.15406/jamb.2017.05.00140

[35] Botello, A.V., Villanueva, F.S., Rivera, R.F., Velandia, A.L. and De la Lanza-Espino, G. (2018) Analysis and Tendencies of Metals and POPs in a Sediment Core from the Alvarado Lagoon System (ALS), Veracruz, Mexico. Archives of Environmental Contamination and Toxicology, 75, 157-173. https://doi.org/10.1007/s00244-018-0516-Z

[36] Lorenzo-Flores, A., Giácoman-Vallejos, G., Ponce-Caballero, M.C. and Ghoveisi, H. (2017) Adsorption of Organophosphorus Pesticides in Tropical Soils: The Case of Karst Landscape of Northwestern Yucatan. Chemosphere, 166, 292-299. https://doi.org/10.1016/j.chemosphere.2016.09.109

[37] Mamta, Rao, R.J. and Wani, K.A. (2015) Monitoring of Organochlorine and Organophosphorus Pesticide Residues in Water during Different Seasons of Tighra Reservoir Gwalior, Madhya Pradesh, India. Environmental Monitoring and Assessment, 187, 684. https://doi.org/10.1007/s10661-015-4889-4 